\title{
Preliminary experiments on the artificial feeding of Mugilidae
}

\author{
F. Vallet, J. Berhaut, C. Leray, B. Bonnet and P. Pic \\ Station Marine d'Endoume et Centre d'Océanograpbie; Marseille, France
}

EXTRAIT: Premiers essais de nutrition artificielle chez les Mugilidae. Les principales caractéristiques de la nutrition artificielle sont étudiées dez de jeunes Mugil auratus et Mugil capito. Nous soulignons l'importance de la teneur en protéines dans l'aliment chez les alevins et la nécessité des glucides chez les individus plus âgés. L'urée est susceptible d'être utilisée comme source d'azote non indispensable pour maintenir un poids constant chez des animaux à jeûn. La ration journalière d'entretien à $15^{\circ} \mathrm{C}$ s'élève à $0,92 \mathrm{Cal}$. pour un poisson de $10 \mathrm{~g}$ et une ration de 1,88 Cal. assure une croissance en poids de 7,3\% en trois semaines. L'incorporation de cellulose dans l'aliment diminue la croissance en élevant le taux de conversion. Au cours d'expériences de nutrition à salinités contrôlées, il est apparu que l'élevage en eau de mer diluée $(S=20 \%)$ permet une meilleure utilisation de l'aliment.

\section{INTRODUCTION}

Natural feeding of Mugilidae has been dealt with in numerous papers. In contrast, artificial feeding has, apparently, rarely been attempted, even in countries which operate intensive farms of these commercially important teleost fishes. It appeared to us that knowledge of the optimum nutritional conditions obtained by use of artificial, chemically defined, diets might contribute to a better understanding of the trophic ecology of these fishes which are widely distributed throughout the world.

All experiments, which are briefly described here, have been carried out on adult individuals of Mugil auratus and $M$. capito captured along the shore near Marseilles and kept in tanks of different sizes.

Table 1

Gross composition (in $\%$ ) of the different diets employed

\begin{tabular}{|lcccccc|}
\hline Compounds & A & B & C Diets & D & E & F \\
\hline Proteins & 25 & 72.4 & 75.2 & 60.8 & 45 & 25 \\
Carbohydrates & 71 & 23.6 & 20.8 & 35.2 & 51 & 41.5 \\
Lipids & 4 & 4 & 4 & 4 & 4 & 8.5 \\
Vitamins & 0.015 & 0.015 & 0 & 0 & 0.015 & - \\
Indigestible & 0 & 0 & 0 & 0 & 0 & 25 \\
matter & 0 & 0 & 0 & 0 & \\
\hline
\end{tabular}


The fishes were offered food of varied composition (Tables 1 and 2) every morning, except on Sunday; the food was granulated at low temperatures (maximum $40^{\circ} \mathrm{C}$ ). Any refuse was recovered by sucking it up and straining it over glass wool; it was then desiccated for $24 \mathrm{~h}$ at $110^{\circ} \mathrm{C}$ and weighed.

Table 2

Composition of the vitamin mixture

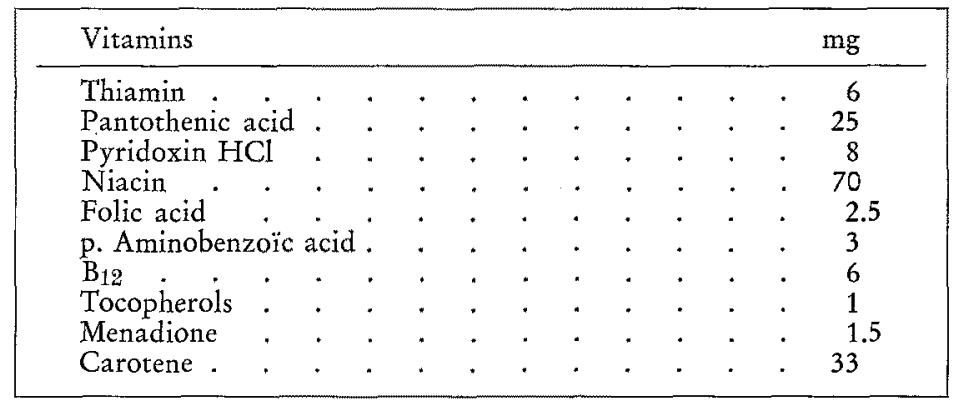

We shall first consider the importance of the origin of the food nitrogen and of the size of the daily food ration. Thereafter we shall assess the influence of the nonnitrogenous remnants and of salts (in food and ambient water), and finally evaluate growth rates and efficiencies of energy turnover.

\section{RESULTS}

Importance of the origin of food nitrogen

A study has been undertaken of the nutrition of 3 groups of mugilid fishes composed of young individuals of average standard lengths of (a) $21 \mathrm{~mm}$ (average wet weight $200 \mathrm{mg}$ ); (b) $36 \mathrm{~mm}$ (average wet weight $800 \mathrm{mg}$ ) and (c) 5 to $15 \mathrm{~cm}$ (average wet weight 3 à $10 \mathrm{~g}$ ).

A preliminary field study of stomach contents revealed that a change occurs in the diet of very young ( $4-5$ months old) individuals.

Stomach contents of fish of standard lengths of 15 to $40 \mathrm{~mm}$, were composed mainly of remains of little Crustacea (Copepoda, Amphipoda) and of Nematoda, indicating an essentially carnivorous diet. Stomach contents of fish of larger size were composed of Diatomea, plant fragments, sand, and mud. These facts have led us to suggest that the diet of these mugilid fishes was mainly herbivorous and detritivorous, but a careful examination showed that plant substance is hardly digested. This observation, already reported by YASHOUV \& BEN-SHACHAR (1967), tends to confirm Odum's opinion (1968), according to which the intestinal flora (bacteria, flagellates) acts as a secondary source of metabolites absolutely necessary for Mugilidae.

This information has prompted us to test artificial diets containing various sorts of food with different percentages of proteins. The food sources tested were either 
plant (yeast protein, diet D) or animal substances (egg albumin, diets A, B, E; Fish, diet $C$ ) or consisted of plant plus animal substances (diet F).

These preliminary experiments were conducted on Mugil auratus (about 400 individuals of an average standard length of $20 \mathrm{~mm}$ ). Maximum growth rates occurred when using a food source with maximum protein content (highest content: $70 \%$ ).
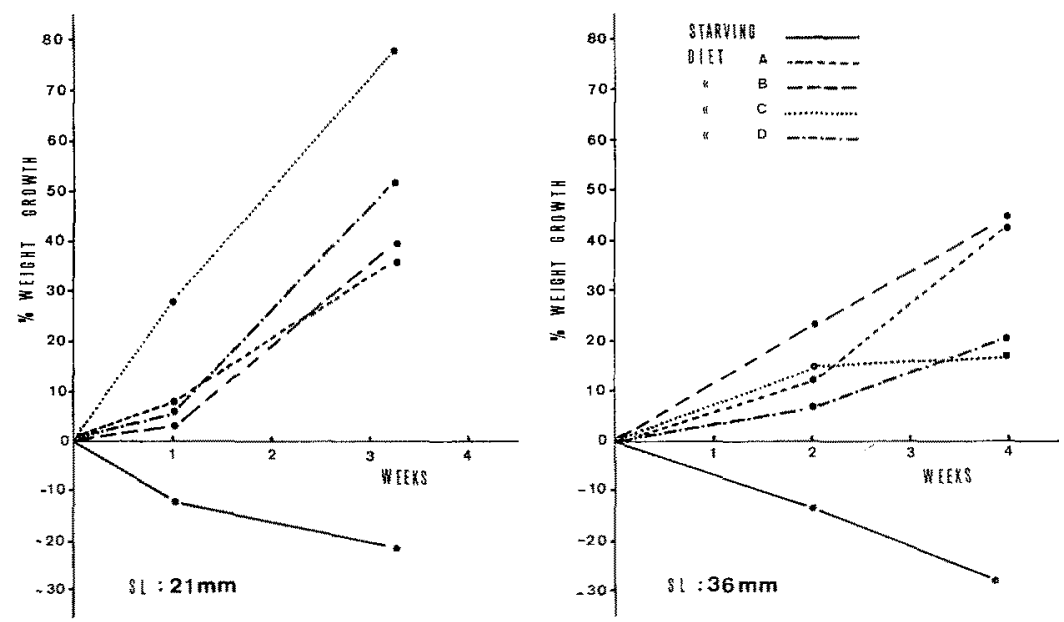

Fig. 1: Growth rates of Mugil capito kept without food (starving) or offered 4 different diets. Left: individuals of $21 \mathrm{~mm}$ total length; right: of $36 \mathrm{~mm}$ total length

Two similar tests were carried out on Mugil capito of different age and length. Group 1 had an average standard length of $21 \mathrm{~mm}$, Group 2 of $36 \mathrm{~mm}$; both groups had 4 different diets (A, B, C, D) and their growth rates compared to an identical, but starving (for 22 days), reference group. The results obtained are summarized in Table 3 and Figure 1.

In group $1(21 \mathrm{~mm}$ ), diets $C$ and $D$ (maximum protein content) result in a significantly faster growth (about twice that obtained with the other two diets). This situation reverses in group $2(36 \mathrm{~mm})$; in this group, food containing $25 \%$ proteins (diet $A$ ) is sufficient to sustain a growth rate identical to that obtained with diet $B$

Table 3

Mugil capito. Growth rates of 2 different size groups (21 and $36 \mathrm{~mm}$ standard length) of starving and fed (4 diets) individuals. $\left(20^{\circ} \mathrm{C} ; 37.5 \% \mathrm{~S}\right)$

\begin{tabular}{|ccccc|}
\hline Diets & $\begin{array}{c}\text { Standard length } \\
\text { Initial wet weight } \\
(\mathrm{mg})\end{array}$ & $\begin{array}{c}21 \mathrm{~mm} \\
\text { Increase } \\
(\% / 0)\end{array}$ & $\begin{array}{c}\text { Standard length } \\
\text { Initial wet weight } \\
(\mathrm{mg})\end{array}$ & $\begin{array}{c}36 \mathrm{~mm} \\
\text { Increase } \\
(\%)\end{array}$ \\
\hline Starvation & 196 & -20.40 & 902 & -28.49 \\
A & 202 & 35.64 & 831 & 41.51 \\
B & 180 & 39.11 & 798 & 41.72 \\
C & 219 & 76.06 & 851 & 17.74 \\
D & 214 & 50.12 & 751 & 19.84 \\
\hline
\end{tabular}


(72.4\% proteins). Compounds of diet B are not well preserved in seawater; this might, in part, explain the last-mentioned result.

The fact that the older fish of group 2 (Fig. 2) gain only half the weight when fed diets $C$ and $D$, (which are equally rich in proteins) indicates that carbohydrates are absolutely necessary at this stage, but less necessary for the younger fish of group 1. These results are in agreement with the change of diet observed in the field and probably correspond to some basic modification in the digestive capacities. Under optimum experimental conditions average weight increase during 3 weeks is twice as high in group 1 as in group 2.

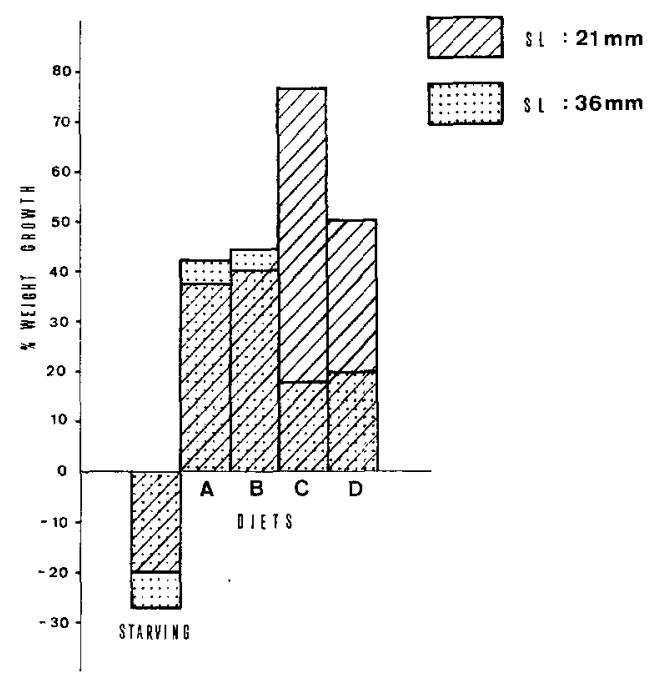

Fig. 2: Growth rates of Mugil capito kept without food or offered 4 different diets. The 2 size groups tested are indicated

A biometric study, now in progress, might enable us to compare field data with these last mentioned experimental values. We may conclude that in intensive farming, which might be achieved in hatcheries, it will be necessary to use a food which is rich in proteins in the first months of the life of the mullet.

Tests undertaken on Mugil capito (average net weight of $3 \mathrm{~g}$ ), using diets with protein contents of $25 \%$ (diet A), $45 \%(\operatorname{diet} E)$ or $72.4 \%$ (diet B), confirm that the protein content exerts little effect on growth rates of large individuals, in spite of a slightly bigger ingestion rate. The high protein contents of diet $B$ result in a weight increase $15 \%$ lower than those obtained with diet $A$ but (as previously noted) this might be due to pollution of the water.

The nature of the protein incorporated in the food does not seem to have any influence on the conversion ratio (dry weight of food ingested divided by increase in body dry weight) since, at a protein content of $25 \%$, this coefficient is 13 for a diet with albumin (diet A), 14 with yeast protein (diet D), and 12.6 with proteins of mixed origin (diet F). 
It appeared of some interest to test whether protein nitrogen might be replaced by urea in the nutrition of young fasting Mugil capito; in this regard, we follow ODum (1968) who emphasized the use of organic compounds by the intestinal flora of adult mullets.

In ruminant mammalians, a great part of the protein nitrogen ingested can be replaced by urea. Numerous studies have shown that protein nitrogen is not absolutely necessary for the rat (AdKrns et al. 1967) or for man (HoLT 1968): urea nitrogen can maintain normal rates of growth and of nitrogen retention.

Table 4

Mugil capito. Weight loss in percent average initial wet weight $(800 \mathrm{mg})$ after 32 day exposure to different concentrations of urea in seawater

\begin{tabular}{|ccccc|}
\hline \multirow{2}{*}{$\begin{array}{c}\text { Urea } \\
(\mathrm{g} / \mathrm{l})\end{array}$} & $\begin{array}{c}\text { From 1 to } \\
\text { 9 days }\end{array}$ & $\begin{array}{c}\text { From } 9 \text { to } \\
\text { 20 days }\end{array}$ & $\begin{array}{c}\text { From 20 to } \\
\text { 32 days }\end{array}$ & $\begin{array}{c}\text { Total } \\
\text { weight loss }\end{array}$ \\
\hline 0 & 22.70 & 9.71 & 9.80 & 42.21 \\
2 & 7.17 & 9.84 & 8.23 & 25.24 \\
4 & 1.48 & 8.93 & 6.28 & 16.69 \\
8 & 11.51 & 10.44 & 8.64 & 30.59 \\
\hline
\end{tabular}

Mugil capito of an average wet weight of $800 \mathrm{mg}$ were kept without food in urea solutions of increasing concentrations $(2,4$ and $8 \mathrm{~g} / 1$ seawater). Over a period of 32 days, we recorded at 10 day intervals the average loss of weight in each batch ( 40 fish per 50 1) together with that of a control kept fasting in seawater without any supplements. In every case it was found that urea moderates the weight loss caused by fasting

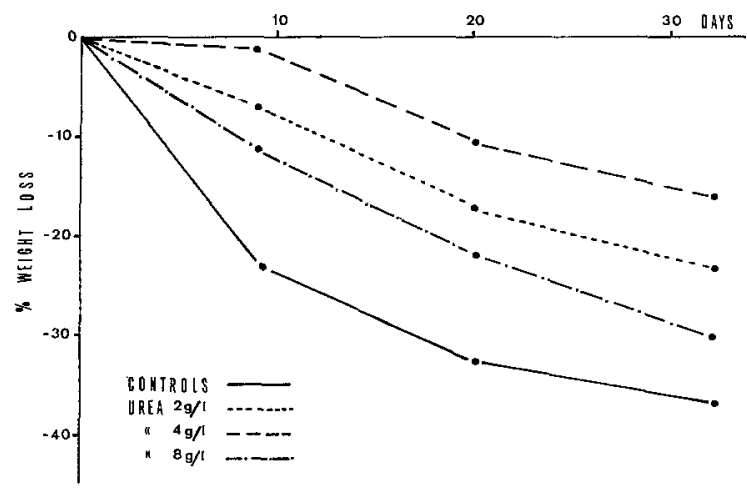

Fig. 3: Weight loss of young Mugil capito kept in seawater, containing urea of different concentrations

(Tab. 4); a concentration of $4 \mathrm{~g}$ urea per litre proved most efficient. This efficiency increases with decreasing test time (Fig. 3). While the reference group lost about $23 \%$ weight in 9 days, fish kept in water enriched with $4 \mathrm{~g}$ urea per litre lost merely $1.5 \%$. It 
is reasonable, therefore, to consider urea as an economic source of nitrogen to be incorporated in the diet of mullets. In India, urea has been used as a general fertilizer for fish ponds. Incorporating urea in pellet food for fish will be possible only after the difficult problem of conservation of pellet food in water has been solved.

\section{Importance of the daily food ration}

Young Mugil auratus of an average wet weight of $10 \mathrm{~g}$ (standard length: $10 \mathrm{~cm}$ ) have been used to determine the most suitable quantity of food to be given to growing fish and to determine their maintenance ration, corresponding to basic metabolic rates. These fish were divided into 6 lots of 15 individuals each which were kept for 21 days at $15^{\circ} \mathrm{C} ; 5$ of these groups received different daily rations ( 2 to $10 \%$ of live weight) of diet A containing $25 \%$ of water, while 1 group was kept fasting during the whole test period.

The results are summarized in Table 5. They show maximum efficiencies at intake rates of $6 \mathrm{~g}$ wet weight for $100 \mathrm{~g}$ weight (or $4.5 \mathrm{~g}$ dry weight). Beyond this value, it was difficult to assess the amount of food left at the bottom of the tank; therefore, we consider the recorded value of $8 \%$ quite approximate; at $10 \%$ estimation becomes impossible. It appears that, in spite of faster growth with $8 \%$ and $10 \%$ rations, the $6 \%$

Table 5

Mugil auratus. Growth rate in percent initial wet weight and food conversion rate. The test fish received for 3 weeks the daily rations indicated

\begin{tabular}{|lcccccc|}
\hline Daily ration $(\%)$ & 0 & 2 & 4 & 6 & 8 & 10 \\
\hline Growth rate & -8.26 & -4 & +2.8 & +7.32 & +8.5 & +11.6 \\
Food conversion rate & - & - & 22.5 & 13 & 14.8 & - \\
\hline
\end{tabular}

ration (1.88 Cal day) represents a convenient compromise between weight increase and food budget. The maintenance ration (nitrogen balance) appears to be about $3 \%$ of the wet weight ( $2.2 \mathrm{~g} \mathrm{dry}$ weight for $100 \mathrm{~g}$ living fish) corresponding to a daily food energy intake of $0.92 \mathrm{Cal}$ for a fish of $10 \mathrm{~g}$ under the above-mentioned experimental conditions. Additional experiments have enabled us to establish that, at a temperature of $20^{\circ} \mathrm{C}$, this ration amounts to approximately $1.58 \mathrm{Cal}$. Regular observations, carried on during the whole test period, indicate that the fish became most excited when fed a ration below maintenance requirements and that this agitation resulted in general mortality about 10 days later ( 30 days after beginning the test). It is important to know that a daily ration too small to maintain basic metabolic rates is worse than fasting; in starving individuals no mortality was observed. This fact, which has not, apparently, been noted previously, is certainly due to the necto-benthic way of life, which compels mugils to spend a lot of energy in search of food. This behaviour is reflected in a basic metabolic rate higher than that of other teleost fishes (DAvis 1968, Davis \& WARREN 1968). 
Conversion rates (which for Mugil auratus have been found to be low) must be established for other species in order to select optimum rates for intensive farming. Further studies are required to find foods containing proteins which have low biological values for other animals and are, therefore, low in price.

\section{Influence of the amount of non-assimilable food components on food conversion}

It is well established that a completely assimilable diet is to be avoided in animal feeding, and that certain quantities of non-assimilable substances improve the protein conversion ratio; this phenomenon is particularly notable in herbivors. In order to examine such effects in Mugilidae, we divided specimens of Mugil auratus (ca. $6 \mathrm{~cm}$ standard length: average weight $4 \mathrm{~g}$ ) into 5 groups and kept them for 6 days in running seawater $\left(15^{\circ} \mathrm{C}\right)$. Isocaloric daily rations $(0.21 \mathrm{Cal} / \mathrm{g}$ body wet weight) were offered of diet A containing various proportions of purified cellulose $(0,10,20,40,60 \%)$. Waste products and non-ingested food were collected regularly.

Table 6

Mugil auratus. Growth rate in percent average initial wet weight and food conversion rate. The test individuals received rations of different cellulose contents but identical calories

\begin{tabular}{|cccccc|}
\hline Lots & $\begin{array}{c}\text { Cellulose } \\
\text { content } \\
(0 / 0)\end{array}$ & $\begin{array}{c}\text { Consumed } \\
\text { food } \\
\text { substances } \\
\text { (dry weight) }\end{array}$ & $\begin{array}{c}\text { Total } \\
\text { fish } \\
\text { weight }\end{array}$ & $\begin{array}{c}\text { Growth } \\
\text { rate }\end{array}$ & $\begin{array}{c}\text { Food } \\
\text { conversion } \\
\text { rate }\end{array}$ \\
\hline 1 & 0 & 7.2 & 24 & +5.8 & 5.14 \\
2 & 10 & 4.8 & 15.9 & -1.25 & -13.2 \\
3 & 20 & 6.6 & 22 & +2.27 & 27 \\
4 & 40 & 5.4 & 18.7 & +1.06 & -5.4 \\
\hline
\end{tabular}

From Table 6 it becomes evident that the cellulose unfavourably modifies the conversion rate (about 5). It seems, therefore, that the indigestible matter in the food interferes with absorption and, that in spite of the length of the digestive tract of the fish (ratio digestive tract length versus body length 3 ) completely assimilable food is very well utilized for growth. Further experiments are, however, necessary before definite conclusions can be reached. It may be possible, by using food composed of cellulose or inorganic compounds (diatom tests, limestone, etc.) to solve the problem of possible cellulose digestion by Mugilidae (Odum 1968). Such capacity is probably not very common in Mugilidae since vegetable fragments are very rarely found among their stomach contents (eg. in Mugil labeo).

\section{Influence of salts}

While studying the osmotic regulation in Mugil auratus, we were able to estimate the influence of a salt mixture on growth. This mixture (Tab. 7) added to diet A in the 
ratio $1: 15$, slightly favours the growth over a 9 day period of nutrition without improving the efficiency; for the amount of food ingested increases. Joint tests will have

Table 7

Composition of salt mixture

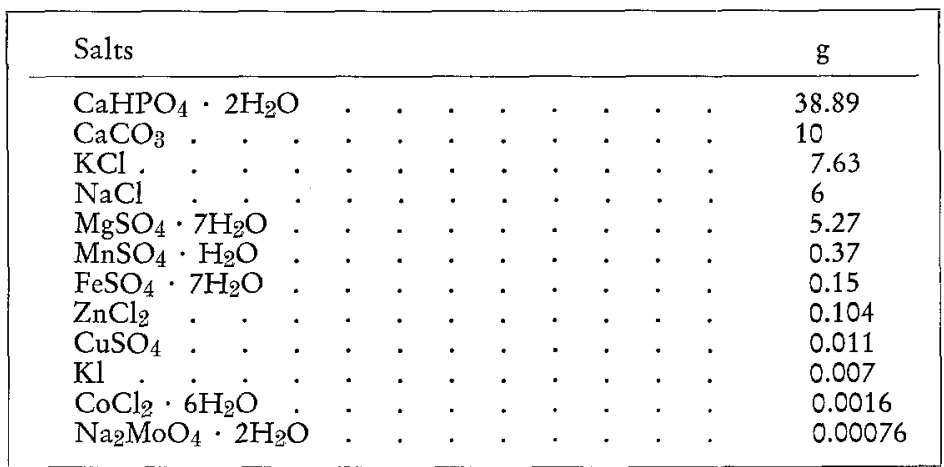

to be undertaken to find out if it will be necessary to add certain salts to the food (calcium salts, for example), and if it will be beneficial to add others (potassium salts). These tests will be all the more necessary as the farming of these fishes takes place in more or less dilute seawater.

\section{Influence of salinity}

Previous studies have shown that thyroid activity in Mugil auratus varies according to the ambient salinity. The variation curve shows two peaks of activity for salinities of 5 and $20 \%$; intermediate salinity of $12 \%$ causes hypothyroid activity. In order to relate the efficiency of a given diet with thyroid activity, we fed diet A (at a rate of $5 \%$ live weight daily to young $M$.auratus (average wet weight $5 \mathrm{~g}$ ) divided into 4 lots of about 30 individuals each. These were kept 11 days at $16^{\circ} \mathrm{C}$ in salinities of 5 , 12,20 or $37.5 \%$. The refuse was recovered after $3 \mathrm{~h}$ feeding.

Under the same experimental conditions as those previously noted the maintenance ration was about $3.3 \mathrm{~g}$ dry weight for $100 \mathrm{~g}$ living fish (Tab. 8) $(0.73 \mathrm{Cal}$ for a $5 \mathrm{~g}$ fish). The increase of $50 \%$, compared with earlier experiments is, no doubt, connected with the lower average weight of these fish $(5 \mathrm{~g}$ instead of $10 \mathrm{~g})$. It is clear that a ration around the maintenance ration in $37.5 \% \mathrm{~S}$ allows good growth at $20 \%$ and $12 \% \mathrm{~S}$; an even more important gain of energy at $5 \% \mathrm{~S}$ cannot prevent a $6.2 \%$ weight loss. In $12 \% \mathrm{~S}$, the high mortality reveals a lack of physiological equilibrium (Fig. 4). Moreover, two different states of thyroid activity (at 12\% and $20 \% \mathrm{~S}$ ) are associated with two different rates of growth and two closely similar conversion efficiencies; which again illustrates the problem of the effect of the thyroid gland on the growth of fish.

It would be interesting and practical to rear Mugil auratus (and probably many others) in a medium with half the salinity of seawater (minimum mortality: maximum 
Table 8

Mugil auratus. Growth rate in percent average initial wet weight and food conversion rate observed in groups kept at different salinities

\begin{tabular}{|ccccc|}
\hline S $(\%)$ & $\begin{array}{c}\text { Consumed nutritive } \\
\text { substances } \\
\text { (dry weight) }\end{array}$ & $\begin{array}{c}\text { Growth } \\
\text { rate }\end{array}$ & $\begin{array}{c}\text { Food } \\
\text { conversion } \\
\text { rate }\end{array}$ & $\begin{array}{c}\text { Mortality } \\
(\%)\end{array}$ \\
\hline 5 & 3.7 & -6.2 & - & 30 \\
12 & 3.1 & +2.4 & 10.7 & 10 \\
20 & 3.5 & +3 & 9 & 3.3 \\
37.5 & 3.3 & -0.2 & - & 3.5 \\
\hline
\end{tabular}

efficiency). Mediterranean Mugilidae are usually found in such salinity during their trophic phase.

In the near future, complementary tests to evaluate the influence of each salt and its relative concentration, will be undertaken. This study, complemented by physiological research, should be done for each fish species whose farming is considered desirable, so as to determine optimum environmental conditions for cultivation.

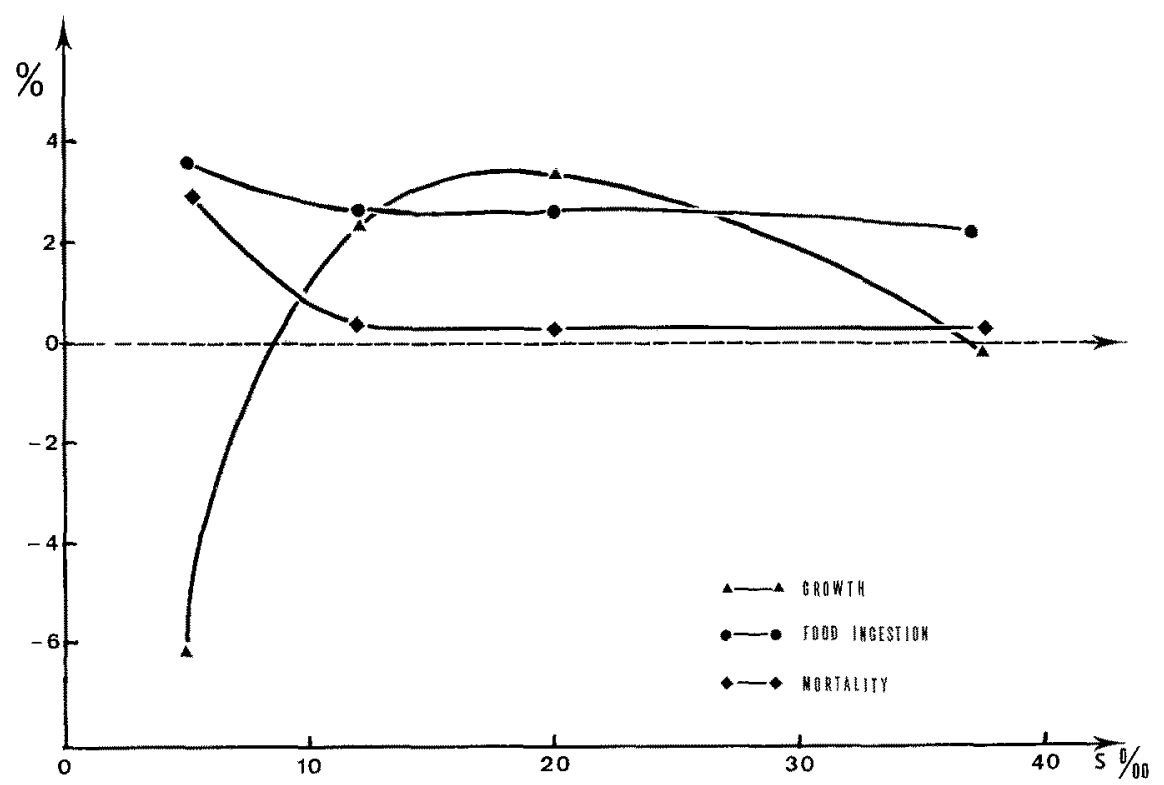

Fig. 4: Growth, food ingestion and mortality observed in Mugil auratus kept in different salinities

\section{SUMMARY}

1. A diet rich in proteins is necessary for the growth of very young Mugil auratus and $M$. capito (standard length: $21 \mathrm{~mm}$ ). As soon as the natural change of diet occurs, a smaller quantity is sufficient. 
2. The nature of proteins, incorporated in the food, does not seem to influence conversion rates.

3. Under conditions of complete starvation, a solution of urea at a concentration of $4 \mathrm{~g} / 1$ reduces weight loss in young Mugil capito (1.5\% instead of $23 \%$ loss after 9 days' starvation).

4. At $15^{\circ} \mathrm{C}, 10 \mathrm{~g}$ Mugil auratus require a daily maintenance ration of $0.92 \mathrm{Cal}$; a ration of $1.8 \mathrm{Cal}$ facilitates a higher growth efficiency ( $7 \%$ in 3 weeks).

5. The addition of non-assimilable components reduces the rate of utilization of assimilable food substances.

6. Salinity influences food conversion rate. A salinity of $20 \%$ affords maximum growth and highest efficiency of food turnover.

\section{LITERATURE CITED}

Adkins, J. S., Wertz, J. M., Boffman, R. H. \& Hove, E. L., 1967. Influence of addition of water or "nonessential" nitrogen on growth of rats fed low levels of essential L-amino acids. Proc. Soc. exp. Biol. Med. 126, 500-504.

Davis, C. C., 1968. Quantitative feeding and weight changes in Poecilia reticulata. Trans. Am. Fish. Soc. 97, 22-27.

Davis, G. E. \& Warren, C. E., 1968. Estimation of food consumption rates. In: Methods for assessment of fish production in fresh waters. Ed. by W. E. Ricker. Blackwell, Oxford, 204-225. (International Biological Program. Handbook. No. 3.)

Hour, L. E., 1968. Some problems in dietary amino acid requirements. Am. J. clin. Nutr. 21, 367-375.

ODUM, W. E., 1968. Utilization of the direct grazing and plant detritus food chains by the striped Mullet Mugil cephalus. In: Symposium on marine food chains, Aarhus 1968. Ed. by J. H. Steele. Oliver \& Boyd, London.

Trompson, J. M., 1966. The grey Mullets. Oceanogr. mar. Biol. A. Rev. 4, 301-335.

Yashouv, A. \& Ben-SHachar, A., 1967. Breeding and growth of Mugilidae. II. Feeding experiments under laboratory conditions with Mugil cephalus L. and Mugil capito (CUVIER). Bamidgeh 19, 50-66.

First author's address: Dr. F. VALLET

Faculté des Sciences de Marseille

Station Marine d'Endoume

Rue de la Batterie des Lions

Marseille 7e, France 